\title{
Reflection of serum immunoglobulin isotypes in the egg yolk of laying hens immunized with enterotoxigenic Escherichia coli
}

\author{
Nagendra Nath Barman ${ }^{1}$, Anjan J yoti Nath² and Niranjan Kalita ${ }^{3}$ \\ 1. Department of Microbiology, College of Veterinary Science, Khanapara, Guwahati, Assam, India; 2. Pasteur Institute \\ of India, Coonoor, Nilgiris, Tamil Nadu, India; 3. Department of Poultry Science, College of Veterinary Science, \\ Assam Agricultural University, Khanapara, Guwahati, Assam, India. \\ Corresponding author: Nagendra Nath Barman, e-mail: nnbarman@gmail.com, \\ AJ N: drnath76@gmail.com, NK: niranjankalita@gmail.com \\ Received: 27-05-2014, Revised: 10-08-2014, Accepted: 19-08-2014, Published online: 30-09-2014
}

doi: 10.14202/vetworld.2014.749-753. How to cite this article: Barman NN, Nath AJ, Kalita N (2014) Reflection of serum immunoglobulin isotypes in the egg yolk of laying hens immunized with enterotoxigenic Escherichia coli, Veterinary World 7(9): 749-753.

\begin{abstract}
Aim: The aim was to study the seroconversion and development of egg yolk immunoglobulins in adult laying White Leghorn hens immunized against an isolate of enterotoxigenic Escherichia coli (ETEC) bearing K91 and K88ac antigens, obtained from diarrheic piglet.

Materials and Methods: Adult laying White Leghorn hens were immunized with inactivated enterotoxic E. coli strain isolated originally from a case of piglet diarrhea following recommended schedule. The development of whole antibodies and isotype-specific antibodies in serum and egg yolk were measured using indirect enzyme-linked immunosorbent assay (ELISA). Piglets suffering from diarrhea with fecal samples positive for ETEC were fed with egg yolk and compared with diarrheic control group.

Results: The serum and egg yolk ELISA antibody titer against E. coli strain used in the present study was as high as $2666.66 \pm 307.92$ and $933.33 \pm 203.67$ respectively on 50 day-post-vaccination (DPV). The immunoglobulin Y (IgY)

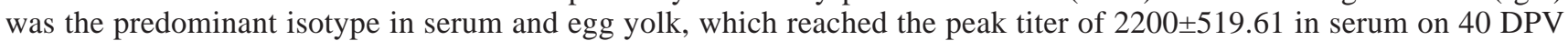
and $800 \pm 244.94$ in egg yolk on 50 DPV. IgM titer in serum and egg yolk was found to be meager, and no IgA could be detected. Diarrheic piglets fed with the egg yolk suspension from immunized hens showed a promising result in controlling diarrhea.
\end{abstract}

Conclusion: Egg yolk antibodies are considered a suitable immunotherapeutic alternative to conventional antibiotic therapy. High titer of egg yolk antibodies raised in the immunized hen against an isolate of ETEC holds the potential to be used for passive protection of diarrheic piglets during their most susceptible period of infection.

Keywords: egg yolk antibodies, enterotoxigenic Escherichia coli, immunization.

\section{Introduction}

Enteric infection in newborn farm animals causes significant economic loss to the milk and meat industry. During the first few days of life, piglets are susceptible to a wide variety of enteric infection among which enterotoxigenic Escherichia coli (ETEC), either alone or in combination with other enteric pathogens, causes significantly high morbidity and mortality [1,2]. Treatment with antibiotic and passive protection with homologous (e.g., colostrum of dam immunized against specific agents) and heterologous antibodies (e.g., egg yolk, colostrum of other species etc.) are the common approaches followed to protect the newborn. Although antibiotic is frequently used to control such infections, development of bacterial resistance, presence of drug residues in end product etc., [3] limits their use. Active immunization, on the other hand, cannot induce instant protective immunity during the most vulnerable period of infection in neonates. Colostum of immunized dam, although

Copyright: The authors. This article is an open access article licensed under the terms of the Creative Commons Attributin License (http:// creative commons.org/licenses/by/2.0) which permits unrestricted use, distribution and reproduction in any medium, provided the work is properly cited. give protection, has to be planned well in advance and should cover immunizing the entire herd.

Heterologous antibodies from immunized animals involve various constraints, including cost of production, quantum produced and even the animal ethical concerns. However, for passive protection approach heterologous antibodies raised against different pathogens in egg yolk or cow colostrum etc., have been explored in various studies [4-9]. Egg yolk antibody (immunoglobulin Y [IgY]) is easier to raise, economical, and also it addresses the most criticized ethical concern of animal use. IgY, the mammalian equivalent of IgG, is concentrated in the egg yolk up to $25 \mathrm{mg} / \mathrm{ml}$ [10]. Antibodies developed against several microorganisms in the egg yolk of hens has been proved to be a suitable alternative in terms of reducing and refining animals use when compared to raising immunoglobulin in other mammals for immunodiagnostic as well as immunotherapeutic purposes [11].

Hence, in this study, the reflection of immunization of laying hens in egg yolk was explored along with the possibilities of using egg yolk of immunized hen to control diarrhea in ETEC infected piglets. 


\section{Materials and Methods}

\section{Ethical approval}

The animals used for raising antibody and protection study was approved by Institutional Animal Ethics Committee and maintained as per the guidelines of the committee for the purpose of control and supervision of experiments on animals.

\section{Materials studied}

The study materials consisted of serum and egg yolk samples of immunized hens against an isolate of ETEC bearing K91 and K88ac antigens, obtained from diarrheic piglet and fecal sample/swab from the piglets fed with the egg yolk in the protection study.

\section{Study area}

This study was conducted in adult laying White Leghorn hens raised in the Instructional Poultry Farm, College of Veterinary Science, Khanapara, Assam and the protection study was conducted in neonatal piglets maintained in clean air station at Department of Microbiology, College of Veterinary Science, Khanapara, Assam.

\section{Study methods}

ETEC originally isolated from a piglet with diarrhea in Department of Microbiology, College of Veterinary Science, Khanapara, Guwahati, Assam, was used. The E. coli isolate was identified as O-149 serotype and contained labile toxin, stable toxin a (STa) and STb enterotoxins. The strain is characterized as bearer of K91 and K88ac antigens using specific monoclonal antibodies by enzyme-linked immunosorbent assay (ELISA).

Adult laying White Leghorn hens (12 Nos.) from the Instructional Poultry Farm, College of Veterinary Science, Khanapara were immunized with ETEC. The organism was grown in minca broth (Difco) at $37^{\circ} \mathrm{C}$ with shaking for $24 \mathrm{~h} ; 2 \times 10^{10} \mathrm{CFU}$ of the organisms was suspended in $1 \mathrm{ml}$ phosphate-buffered saline (PBS) (pH 7.4), inactivated with $0.4 \%$ (v/v) formaldehyde at $4^{\circ} \mathrm{C}$ for $24 \mathrm{~h}$ and precipitated by $10 \%(\mathrm{w} / \mathrm{v})$ solution of aluminum potassium sulfate and $7.4 \%$ $(\mathrm{w} / \mathrm{v})$ solution of potassium hydroxide. Inactivated bacterial suspension $(0.5 \mathrm{ml})$ was emulsified in equal volume of Freund's adjuvant (Sigma Chemical Co.) and three divided parts injected intramuscularly into upper thighs and breast muscle. Subsequently, $1 \mathrm{ml}$ booster injections of inactivated ETEC emulsified in Montanide ISA 25 adjuvant (Seppic 75, Quai-d'orsay, Paris) were given in the same manner, 3 times at 10-days interval. The blood samples and the eggs were collected from six of the vaccinated birds on $1^{\text {st }}$ day of immunization and at every 10-day interval up to 50 days of post-immunization. Sera samples and egg yolks were preserved at $-20^{\circ} \mathrm{C}$. For passive immunization of the newborn piglets, the eggs were collected daily from the immunized hens after 10 days of the last injection.

Nunc polystyrene plates were coated overnight with sonicated cultures of ETEC $(1: 100)$ suspended in $0.05 \mathrm{M}$ carbonate-bicarbonate buffer $(\mathrm{pH} \mathrm{9.6)}$ at $4^{\circ} \mathrm{C}$. Aliquots of $50 \mu \mathrm{l}$ were used throughout. After thorough washing with PBS-Tween, the wells were blocked with 3\% bovine serum albumin (BSA, Sigma Chemical Co.). Serial two-fold dilution of the samples (serum or egg yolks) was made starting from 1:100 in antigen coated duplicate plates and incubated. Plates were washed again. For the detection of antibody against ETEC bacteria, rabbit anti-chicken peroxidase conjugate (1:3000; Sigma Chemical Co.) was added in one plate. In a duplicate plate, to detect isotype specific anti-ETEC antibodies, anti-chicken IgA (1:4000), IgM (1:2000) and IgG (1:1000) of Serotec Laboratory Service, were added. After thorough washing, peroxidase labeled rabbit anti-goat or goat anti-rabbit conjugate (1:3000; Sigma Chemical Co.) was added in duplicate plate. The incubations and washing steps were repeated, and amount of bound conjugate was visualized by use of OPD (Sigma Chemical Co.) and $\mathrm{H}_{2} \mathrm{O}_{2}$. The color reaction was stopped after 15 min incubation and read the plates by ELISA reader (MRX, Dynatech) at $490 \mathrm{~nm}$. Each test was accompanied by ETEC bacterial suspension (1:100) as positive antigen, minca broth as negative antigen, serum and egg yolk controls. Incubation was done at $37^{\circ} \mathrm{C}$ for $1 \mathrm{~h}$. Corrected OD (mean OD of test sample-mean OD of negative control) value at highest dilution of the test sample $\geq 0.1$ was considered as titer of antibodies in serum or egg yolk.

\section{Protection study}

Piglets $(n=15)$ in the age group of 0-10 days, suffering from clinical diarrhea and the fecal samples positive for ETEC antigen (as detected by ELISA) were selected for the protection study. Egg yolks separated from the whites were pooled together and mixed with an equal volume of $0.05 \mathrm{M}$ carbonate bi-carbonate buffer (pH 9.6). The piglets were divided into two groups. Group A ( $\mathrm{n}=10)$ was fed with $15 \mathrm{ml}$ egg yolk mixture (approximately one egg yolk volume) daily for 5 days. The control Group B $(n=5)$ was maintained without egg yolk. The piglets were kept in a clean air station and provided sterilized milk replacer and oral rehydration solution throughout the experiment period. The clinical score and diarrheic score was recorded before and after the initiation of protection study.

The clinical and fecal scores were recorded according to Lanza et al. [12]. The clinical scores ranged from 0 to 3 and based on the rise of body temp and loss of body weight per week. The fecal scores were fixed between 0 and 3 and on the basis of fecal consistency and excretion of ETEC. Rectal swabs were collected daily up to 7 days post-exposure, and $E$. coli was isolated on eosin methylene blue agar as well as on blood agar. Typical randomly selected colonies per plate were identified by ELISA for K88ac bearing ETEC organisms. 


\section{Results}

Boosters given at 10 days intervals for 3 occasions raised the antibody level gradually up to the last day (50 ${ }^{\text {th }}$ day) of our study period, i.e. $20^{\text {th }}$ day after the last booster. Antibody to ETEC was detected in the serum of immunized hen at 10 day of the first immunization $(100 \pm 0.00)$ (Table-1). The antibody titers reached peak at 50 day-post-vaccination (DPV), and the mean titer was 2666.66 \pm 307.92 . The IgY was the predominant isotype in the serum of the vaccinated birds and persisted

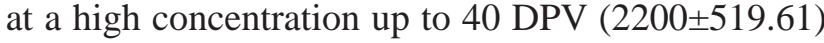
and declined slightly to $1900 \pm 653.83$ on 50 DPV. The IgM was developed at a low level (133.33 \pm 27.21$)$ and maintained the same level up to 50 DPV. However, ETEC-specific IgA immunoglobulin could not be detected. Antibodies against ETEC bacteria developed in the serum have reflected in the egg yolk of the immunized hen (Table-2). The antibody on egg yolk appeared at $20 \mathrm{DPV}(166.66 \pm 19.24)$ and increased gradually (300 \pm 40.82 on $30 \mathrm{DPV}, 533.33 \pm 76.98$ on $40 \mathrm{DPV})$ up to $50 \mathrm{DPV}(933.33 \pm 203.67)$. The most common isotype in the yolk of the vaccinated hen was IgY and it persisted at a high concentration up to $50 \mathrm{DPV}(125 \pm 41.45,250 \pm 43.30,450 \pm 108.97$ and $800 \pm 244.94$ on 20,30, 40 and 50 DPV respectively). ETEC specific IgM was present at low concentration (133.33 $\pm 27.21,150 \pm 25.00$ and $125 \pm 21.65$ on 30,40 and $50 \mathrm{DPV}$, respectively). However, IgA could not be detected in yolk.

\section{Result of protection study}

The piglets fed with immune egg yolk (Group A) survived the study period with $100 \%$ clinical recovery from diarrhea within a short duration of 24-48 h
(Table-3). Piglets receiving immune egg yolk had gained more weight. All the control piglets (Group B) succumbed after 2-4 days of illness. The mean clinical and fecal score differed significantly $(\mathrm{p}<0.05)$ between Group A and Group B. The ETEC was detected from the rectal swabs of all piglets at the beginning of the study and up to $24 \mathrm{~h}$. The mean viable colonies of ETEC were more in control piglets (Group B). The ETEC were excreted persistently in Group B piglets until they succumbed on day 4-5. In piglets fed with immune egg yolks (Group A), the excretion of ETEC bacteria was ceased after 4 days postinfection.

\section{Discussion}

The egg yolks of the hens are a rich source of immunoglobulins [11]. The serum antibodies developed in the vaccinated hens are actively transported to egg yolk and remained there in high titers [13]. The development of antibodies in immunized hens and their subsequent transfer to the egg yolk depends on several factors namely immunization schedule, route of application, adjuvant used, antigen dose, and the animal factors such as breed, age, keeping condition of chicken, etc. [14]. In the present study, repeated immunization of laying hens with adjuvant ETEC vaccine efficiently elevates serum antibody titers and high antibody concentration persisted even after 20 days of last vaccination. Our study showed a gradual increase of antibody titer up to $50^{\text {th }} \mathrm{DPV}$. Though the present study clearly showed that the antibodies developed in the serum is mirrored in the yolk, it is still in contrary to the findings of other workers that all the antibodies in serum gets transferred to the yolk [15], or the titer in the yolk is up to

Table-1: Whole antibody titres and isotype-specific antibody titres against K88ac ETEC in serum of immunized hens as determined by indirect ELISA.

\begin{tabular}{|c|c|c|c|c|}
\hline \multirow{2}{*}{$\begin{array}{l}\text { Day of } \\
\text { collection }\end{array}$} & \multirow{2}{*}{$\begin{array}{c}\text { Mean }( \pm S E) \text { titre of } \\
\text { whole antibody }(n=6)\end{array}$} & \multicolumn{3}{|c|}{ Mean $( \pm)$ SE titre of isotype specific antibodies } \\
\hline & & $\operatorname{lgA}(n=4)$ & $\lg M(n=4)$ & $\operatorname{lgG}(n=4)$ \\
\hline 0 & - & - & - & - \\
\hline 10 & - & - & - & $100.00( \pm 0.00)$ \\
\hline 20 & $216.66( \pm 36.64)$ & - & $133.33( \pm 27.21)$ & $300.00( \pm 50.00)$ \\
\hline 30 & $500.00( \pm 91.28)$ & - & $125.00( \pm 21.65)$ & $850.00( \pm 248.74)$ \\
\hline 40 & $1733.33( \pm 293.13)$ & - & $133.33( \pm 27.21)$ & $2200.00( \pm 519.61)$ \\
\hline 50 & $2666.66( \pm 307.92)$ & - & $125.00( \pm 21.65)$ & $1900.00( \pm 653.83)$ \\
\hline
\end{tabular}

Antibody titres in the serum of un-vaccinated control birds were $<100, n=$ Number of birds, $-=$ Titres $<100$.

$\mathrm{ETEC}=$ Enterotoxigenic Escherichia coli, ELISA=Enzyme-linked immunosorbent assay, SE=Standard error

Table-2: Whole antibody tittres and isotype-specific antibody tittres against K88ac ETEC in egg yolk of immunized hens as determined by indirect ELISA.

\begin{tabular}{|c|c|c|c|c|}
\hline \multirow{2}{*}{$\begin{array}{l}\text { Day of } \\
\text { collection }\end{array}$} & \multirow{2}{*}{$\begin{array}{c}\text { Mean ( } \pm \text { SE) titre of } \\
\text { whole antibody }(n=6)\end{array}$} & \multicolumn{3}{|c|}{ Mean $( \pm S E)$ titre of isotype specific antibodies } \\
\hline & & $\lg A(n=4)$ & $\lg M(n=4)$ & $\operatorname{lgG}(n=4)$ \\
\hline 0 & - & - & - & \\
\hline 10 & - & - & - & \\
\hline 20 & $166.66( \pm 19.24)$ & - & - & $125.00( \pm 41.45)$ \\
\hline 30 & $300.00( \pm 40.82)$ & - & $133.33( \pm 27.21)$ & $250.00( \pm 43.30)$ \\
\hline 40 & $533.33( \pm 76.98)$ & - & $150.00( \pm 25.00)$ & $450.00( \pm 108.97)$ \\
\hline 50 & $933.33( \pm 203.67)$ & - & $125.00( \pm 21.65)$ & $800.00( \pm 244.94)$ \\
\hline
\end{tabular}

Antibody titres in the egg yolk of un-vaccinated control hens were $<100, n=$ Number of birds, $-=$ Titres $<100, S E=S t a n d a r d$ error, I $\mathrm{g}=\mathrm{Immunoglobulin}$, ETEC=Enterotoxigenic Escherichia coli, ELISA=Enzyme-linked immunosorbent assay 
Table-3: Protection study in diarrhoeic piglets fed with egg yolk from immunized hens.

\begin{tabular}{lcccccc}
\hline $\begin{array}{l}\text { Animal } \\
\text { group }\end{array}$ & $\begin{array}{c}\text { Number } \\
\text { of piglets }\end{array}$ & $\begin{array}{c}\text { Recovery } \\
\text { diarrhoea/total (\%) }\end{array}$ & $\begin{array}{c}\text { Mean* clinical } \\
\text { score ( } \pm \text { SE) }\end{array}$ & $\begin{array}{c}\text { Mean* faecal } \\
\text { score ( } \pm \text { SE) }\end{array}$ & $\begin{array}{c}\text { Duration of } \\
\text { diarrhoea (days) }\end{array}$ & $\begin{array}{c}\text { Number of piglets } \\
\text { dead/ total (\% ) }\end{array}$ \\
\hline A & 10 & $10 / 10(20.00)$ & $0.30^{\mathrm{a}}( \pm 0.15)$ & $0.20^{\mathrm{a}}( \pm 0.13)$ & $1-2$ \\
B & 5 & $0 / 5(0.00)$ & $2.60^{\mathrm{b}}( \pm 0.25)$ & $2.40^{\mathrm{b}}( \pm 0.25)$ & $4-5$ & $5 / 10(00.00)$ \\
\hline
\end{tabular}

*The means bearing different letters as superscripts are significantly different at $\mathrm{P}<0.05$. A=Piglets fed egg yolk from vaccinated hens, $\mathrm{B}=$ Piglets received no egg yolk, SE: Standard error

1.23 times higher than the serum antibody titer [16]. The ETEC specific IgY was predominantly present in the serum and egg yolk. The absence of IgA isotype in the serum and egg yolk suggests that the parenteral immunization do not evoke gut-associated lymphoid tissues to secrete IgA immunoglobulins.

The piglets fed continuously for 5 days with egg yolks from the immunized hens were protected against ETEC diarrhea. The protection was attributable to high titer of ETEC specific IgY isotype in this study. These egg yolk antibodies either inhibited or agglutinated the whole E. coli and thus flushed away due to the peristaltic movement. The present observations supported the findings of other workers, who reported that the piglets fed with high titer of IgY antibodies derived from hen egg could protect against ETEC infection [4], and those fed with high titre of IgG antibodies derived from cattle colostrum could protect against TGEV infection [7,8] and ETEC infection [9]. Use of IgY in purified form or as whole egg yolk is promising in immunotherapy. The immune protection capabilities of egg yolk antibodies raised against various organisms or their components have been studied extensively in various animal models, but with variable protection level. Egg yolk immunoglobulins have been used to prevent other enteric infections such as Vibrio infection in shrimp [17]; rotavirus infection in newborn calves [6] and mice [18]; corona virus infection in calves [19] and a wide range of other enteric pathogens such as Salmonella pullorum, Clostridium perfringens, Campylobacter jejuni and E. coli infection in poultry [5].

However, there are also limitations in the use of egg yolk antibodies. The stability of IgY in low $\mathrm{pH}$ of gastric environment, molecular characteristics of IgY for proteolytic cleavage during the passage through stomach and intestine, heat stability for production of egg powder etc. need special considerations, which make the IgY more susceptible for degradation when compared to its mammalian counterpart, IgG [14]. It is assumed that some of the immunoglobulins may get inactivated due to various factors as discussed above.

In the case of whole egg yolk feeding, it is not the egg yolk antibody alone, that imparts protective effects, but also other components of the egg yolk, which might confer additional protective effect. Egg yolk might coat the intestinal mucosa and prevents adhesion of organisms on the enterocytes. The anti-adhesive effect of some of the components of egg yolk and its derivatives namely sialyloligosaccharide, asialo-yolk derived sialyloligosaccharides, and sialylglycopeptide have been suggested [20]. Hence, feeding immunized hens' whole egg yolk also holds promise because of these additional factors present in the yolk. Such non-specific protection of the egg yolk has been demonstrated against ETEC in rabbit [21].

\section{Conclusion}

Serological studies revealed that the development of ETEC specific antibodies in serum of immunized hen is mirrored in the egg yolk. IgY, the mammalian equivalent of IgG immunoglobulin, is the predominant isotype in serum and egg yolk. The whole egg yolk from the immunized hens could protect ETEC positive diarrheic piglets from clinical diarrhea.

\section{Authors' Contributions}

NNB: Planning and carrying out the study, sample processing and serological assay; AJN: Sample processing and serological assay, data analysis, preparation and revision of the manuscript; NK: Raising hyperimmune sera and providing poultry farm facility. All authors read and approved the final manuscript.

\section{Acknowledgments}

We thank the Scientist, Network Project on Pigs, Indian Council of Agricultural Research, Khanapara for providing necessary facilities and Dr S. Sahu, Pasteur Institute of India, Coonoor for valuable inputs in writing the manuscript. Research grant was provided by the Assam Agricultural University under head Post graduate Research.

\section{Competing Interests}

The authors declare that they have no competing interests.

\section{References}

1. Do, T.N., Cu, P.H., Nguyen, H.X., Au, T.X., Vu, Q.N., Driesen, S.J., Townsend, K.M., Chin, J.J.C., and Trott, D.J. (2006) Pathotypes and serogroups of enterotoxigenic Escherichia coli isolated from pre-weaning pigs in North Vietnam. J. Med. Microbiol., 55: 93-9.

2. de la Fé Rodríguez, P.Y., Martin, L.O.M., Muñoz, E.C., Imberechts, H., Butaye, P., Goddeeris, B.M. and Cox, E. (2013) Several enteropathogens are circulating in suckling and newly weaned piglets suffering from diarrhea in the province of Villa Clara, Cuba. Trop. Anim. Health Prod., 45: 435-440.

3. Diraviyam, T., Zhao, B., Wang, Y., Schade, R., Michael, A. and Zhang, X. (2014) Effect of chicken egg yolk antibodies (IgY) against diarrhea in domesticated animals: A systematic review and meta-analysis. PLoS One., 9: 1-14.

4. Liou, J.F., Shiau, J.W., Tai, C. and Chen, L.R. (2011) 
Production of egg yolk immunoglobulin against Escherichia coli from white leghorn and lohmanns chickens. J. Anim. Vet. Adv., 10: 2349-2356.

5. Tamilzarasan, K.B., Dinakaran, M.A., Selvaraju, G. and Dorairajan, N. (2009) Efficacy of egg yolk immunoglobulins (IgY) against enteric pathogens in poultry. Tamilnadu $\mathrm{J}$. Vet. Anim. Sci., 5: 264-268.

6. Vega, C., Bok, M., Chacana, P., Saif, L., Fernandez, F. and Parreno, V. (2011) Egg yolk IgY: Protection against rotavirus induced diarrhea and modulatory effect on the systemic and mucosal antibody responses in newborn calves. Vet. Immunol. Immunopathol., 142: 156-169.

7. Wesley, R.D., Woods, R., Correa, I. and Enjuanes, L. (1988) Lack of protection in vivo with neutralizing monoclonal antibodies to transmissible gastroenteritis virus. Vet. Microbiol., 18: 197-208.

8. Saif, L.J., Van Cott, J.L. and Brim, T.A. (1994) Immunity to transmissible gastroenteritis virus and porcine respiratory corona virus infection in swine. Vet. Immunol. Immunopathol., 43: 89-97.

9. Barman, N.N., Sarma, D.K. and Neog, B.N. (2011) Elimination of enterotoxigenic Escherichia coli in experimentally infected piglets by passive immunization with bovine colostral antibodies. Vet. Arhiv., 71: 381-387.

10. Rose, M.E., Orlans, E. and Buttress, N. (1974) Immunoglobulin classes in the hen's egg: Their seg-regation in yolk and white. Eur. J. Immunol., 4: 521-523.

11. Marcq, C., Théwis, A., Portetelle, D. and Beckers, Y. (2013) Refinement of the production of antigen- specific hen egg yolk antibodies (IgY) intended for passive dietary immunization in animals. A review. Base [En ligne]. 17: 483-493.

12. Lanza, I., Shoup, D.I. and Saif, L.J. (1995) Lactogenic immunity and milk antibody isotypes to transmissible gastroenteritis virus in sows exposed to porcine respiratory corona virus during pregnancy. Am. J. Vet. Res., 56: 739-747.
13. Sentila, R., Karthika, S., Subbraj, T., Diraviyam, T. and Michael A. (2011) Chicken egg yolk antibodies as a key to unlock the antibiotic bondage. EJ. Life Sci., 1: 1-4.

14. Schade, R., Calzado, E.G., Sarmiento, R., Chacana, P.A., Porankiewicz-Asplund, J., and Terzolo H.R. (2005) Chicken egg yolk antibodies (IgY-technology): A review of progress in production and use in research and human and veterinary medicine. ATLA-Altern. Lab. Anim., 33: 129-154.

15. Morrison, S.L., Mohammed, S.M., Wims, L.A., Trinh, R. and Etches, R. (2001) Sequences in anti - Body molecules important for receptor-mediated transport into the chicken egg yolk. Mol. Immunol., 38: 619-625.

16. Woolley, J.A. and Landon, J. (1995) Comparison of antibody production to human interleukin-6 (IL-6) by sheep and chickens. J. Immunol. Methods., 178: 253-265.

17. Prasad, P.K. and Rao, S.P. (2013) Passive protection of shrimp against Vibrio alginolyticus infection by egg yolk antibody supplemented feed. Indian Vet. J., 90: 52-53.

18. Bartz, C.R., Conklin, R.H., Tunstall, C.R. and Steek, J.H. (1980) Prevention of murine rotavirus infection with chicken egg yolk immunoglobulins. J. Infect. Dis., 142: 439-441.

19. Ikemori, Y., Ohta, M., Umeda, K., Lcatlo, F.C.Jr., Kuroki, M., Yokoyama, H. and Kodoma, Y. (1997) Passive protection of neonatal calves against bovine coronavirus-induced diarrhoea by administration of egg yolk or colostrum antibody powder. Vet. Microbiol., 58: 105-111.

20. Sugita-Konishi, Y., Sakanaka, S., Sasaki, K., Juneja, L.R., Noda, T. and Amano, F. (2002) Inhibition of bacterial adhesion and Salmonella infection in BALB/c mice by sialyloligosaccharides and their derivatives from chicken egg yolk. J. Agric. Food Chem., 50: 3607-3613.

21. O'Farrelly, C., Branton, D. and Wanke C.A. (1992) Oral ingestion of egg yolk immumoglobulin from hens immunized with an enterotoxigenic Escherichia coli strain prevents diarrhoea in rabbits challenged with the same strain. Infect. Immunol., 60: 2593-2597. 